\title{
Study on the restricting factors of interest rate and exchange rate linkage effect
}

\author{
Shuangqing Pan ${ }^{1}$ \\ ${ }^{1}$ Quanzhou Normal University, Quanzhou, Fujian Province, China, 362000. \\ Email: shuangqingp@sina.com \\ Corresponding author: Shuangqing Pan
}

\begin{abstract}
In the open economic conditions, interest rate as internal economic imbalance adjustment tool and exchange rate as external economic imbalance adjustment tool are closely related to each other, which have linkage effect. Study on the restricting factors of interest rate and exchange rate linkage effect is important to the stability of economic growth and financial safety. This article indicates that the level of market-driven, economic opening degree and policy objectives of central bank will restrict the linkage effect of interest rate and exchange rate.
\end{abstract}

Keywords: Linkage effect; Interest rate; Exchange rate

\section{Introduction}

Some financial theories like Theory of Interest Rate Parity, [1] Mundell-Fleming Model, [2] Sticky-Price Monetary Approach, [3] Portfolio Balance Model, [4] point out that interest rate and exchange rate are with linkage relationship, but the conclusions are drawn under strict assumptions, factors such as level of market-driven, economic opening degree and policy objectives of central bank in reality will restrict the linkage effect of interest rate and exchange rate. This article analysis influences on interest rate and exchange rate linkage effect from above factors.

\section{The level of market-driven}

The level of a country's financial market-driven plays an important disturbance on the linkage effect of interest rate and exchange rate, low level of the market-driven will restrict the linkage between the two variables, and the high level of market-driven is a necessary condition for a good linkage of the two variables. According to the different market-driven level of interest rate and exchange rate, interest rates can be classified as interest rate regulation and interest rate market-driven, and exchange rate can be classified as exchange fixed rate and floating exchange rate. Interest rate regulation refers to the interest rate is not determined by market but by central bank, policy measures of central bank adjust interest rate to higher or lower than the market equilibrium level. There are two main types of interest rate regulation: a single regulation that only regulates the interest rates of deposits and loans. Another is multiple regulations, not only the interest rates of deposit and loan are regulated, but also the discount rate and price of service are regulated. Fixed exchange rate refers to the exchange rate of the currency for one country with the currency for another country is basically fixed, fixed exchange rate is not completely fixed, it fluctuates around a relatively fixed parity, and the highest point of the range is called the "ceiling", the lowest point is called the "floor". When exchange rate rises or falls to the upper or lower limit, central bank must take intervention measures to make the exchange rate unchanged. Floating exchange rate is symmetrically fixed exchange rate, it fluctuates freely according to the relationship between supply and demand of market, and central bank doesn't intervene it.

The following is to discuss the disturbances of linkage effect of interest rate and exchange rate from different level of market-driven of interest rate and exchange rate, and accord to the level of market-driven of interest rate and exchange rate it can be divided into four situations.

\subsection{Disturbances of interest rate and exchange rate linkage effect from regulated interest rate and fixed exchange rate}

The control of interest rate and fixed exchange rate means that interest rate and exchange rate are not determined by market but by central bank, then in this case the interest rate and the exchange rate are independent exogenous variables, i.e., they are in the economic system, only the role of explanatory variables, only affect the other variables, but not affected by other variables. Of course, there is no linkage whatsoever between the two, or the interest rate control and fixed exchange rate completely blocked the linkage between interest rate and exchange rate. 


\subsection{Disturbances of interest rate and exchange rate linkage effect from regulated interest rate and floating exchange rate}

Regulated interest rate and floating exchange rate indicates that interest rate is exogenous variable, while the exchange rate as internal variable, it means in the economy system, interest rate plays the role of the explanatory variable affecting exchange rate and not be affected by exchange rate. Exchange rate doesn't directly affect interest rate, but it will impact on the central bank's interest rate decision. For example, the devaluation of the currency means price of domestic goods relative to foreign goods is cheap, which is conducive to the country's exports. On the one hand, expanding exports increases demand and pull prices rising; on the other hand, the cost of domestic production increasing, and they push price rising. Therefore, the devaluation would cause inflation, thus forming the pressure on central bank to raise interest rate. If there is no regulation of capital account, the devaluation of the currency could also trigger capital outflows, this also prompt central bank to consider raising interest rate.

\subsection{Disturbances of interest rate and exchange rate linkage effect from market-driven interest rate and fixed exchange rate}

Disturbances of interest rate and exchange rate linkage effect from market-driven interest rate and fixed exchange rate.

Market-driven interest rate and fixed exchange rate indicates that interest rate as an endogenous variable, while exchange rate as an exogenous variable, that is, they are in the economic system, the exchange rate plays the role of the explanatory variable, affect interest rate, and not be affected by the interest rate. Similarly, although interest rate does not directly affect the exchange rate, the changes of it will also impact on the central bank's exchange rate policy. For example, if a country's interest rates is higher than that of another country's, it will attract foreign capital inflow, change supply and demand relations of domestic currency and foreign currency, namely appear excess demand for local currency and excess supply of foreign currency, exchange rate as the price of domestic currency external naturally have the pressure of appreciation.

\subsection{Disturbances of interest rate and exchange rate linkage effect from market-driven interest rate and floating exchange rate}

Market-driven interest rate and floating exchange rate means that the interest rate and exchange rate are endogenous variables, i.e., they can influence each other in the economic system, the linkage between them will form a self balancing mechanism, and achieve the best effect of linkage. If a country's interest rate is higher than that of another country's, it will attract foreign capital inflow, change the supply and demand relations of domestic currency and foreign currency, and appear excess demand for domestic currency and excess supply of foreign currency, then domestic currency appreciating. The appreciation of domestic currency will reduce exports, increase imports, international balance of payments reverses, the devaluation of the domestic currency will generate capital outflow, it change the supply and demand relations of domestic currency and foreign currency once again, namely appear excess supply of domestic currency and excess demand for foreign currency, prompting falling of interest rate. Interest rate and exchange rate is that in a market-driven environment automatically close to their respective equilibrium point.

Ronald I. McKinnon, Kenichi Ohno (1997) [5] think that in a open financial market conditions, there is an intrinsic linkage effect between interest rate and exchange rate, money market and foreign exchange market in a free flow of capital and currency convertibility conditions will gradually mix into one, regulatory acts in a market will directly affect another market quickly.

\section{Economic opening degree}

The degree of openness of a country's economy is often measured by current account convertibility and capital account convertibility, it usually open start from current account convertibility, and then to capital account convertibility. Current account convertibility refers to the company be engaged in import and export business may apply for the foreign currency. Capital account convertibility means not transnational capital transactions restrictions or taking measures may affect the transaction cost related on it, that the cancellation of regulation for funds cross-border transactions and convertibility of the currency. The capital account is not convertible does not mean that the funds will be unable to carry out cross-border transfer, it still exist in reality through false trade transfers of funds from current account and some illegal means to carry funds entry and exit, of course, the transfer cost of funds is relatively large, and the amounts is relatively small.

In general, a country of high degree of opening, non residents enjoy fully national treatment in money market, capital market and foreign exchange market, interest rate and exchange rate are endogenous variables, the linkage effect between them is relatively unaffected, linkage with best effect. A country of low opening degree, not only non residents and even the domestic residents are subject to more stringent restrictions in the money market, capital market and foreign exchange markets, central bank tend to regard interest rate and exchange rate policy as two mutually independent tools, interest rate and exchange rate often belong to external variables, the linkage between 
them will be larger constricted, linkage effect is at a discount.

\section{The policy objectives of central bank}

The policy objectives of central bank in general can be summarized as following four main targets: currency value stability, full employment, economic growth, balance of international payment. Different countries and a country in different period the objectives of central bank policy are different, some for a single policy objective, some for the multiple policy objectives. Differences between the policy objectives of the central bank can affect policies of interest rate and exchange rate, and then affect the linkage effect of interest rate and exchange rate. Below, we discuss it by two conditions of single policy objective and multiple policy objectives.

\subsection{The influence of single policy objective for linkage effect of interest rate and exchange rate}

Countries with single policy objective, they usually choose the currency stability as the only policy objective. The mainstream view for monetary policy of International Monetary Fund and other international financial organizations is also focus on single target to stabilize currency. The goal of "Currency stability" includes two aspects: the stability of internal currency, i.e. price stability; stable foreign currency, namely the stable exchange rate. Because of these two requirements are not always able to take into account at the same time, thus have to choose a main direction.

If it is to stabilize prices primarily, then central bank will mostly depend on the interest rate (discount rate), the statutory reserve rate and open market operation policy, to achieve these goals through control the supply of money. If the domestic inflation, rising prices, then the central bank will raise interest rate, by raising the required reserve ratio, and the issuance of bonds in the open market to withdrawal currency from circulation, in order to control the rising prices; if domestic deflation, falling prices, then the central bank will adopt to lower interest rates, reducing the statutory reserve ratio, as well as in the open market repurchase bonds to release money, in order to control the falling prices.

Because the interest rate policy is the main policy tool of a single policy goal of central bank, so under normal circumstances, direct influence of exchange rate on interest rate is not obvious, while the influence of interest rate on exchange rate will be more obvious. On the national situation of relatively high degree of dependence on foreign trade is different, these countries exchange rate may affect directly to the domestic price level through the influence of export demand and the price of imports, which makes the central bank to take interest rate policy to deal with it, then the impact of exchange rate on interest rates to some degree.
If it is to stabilize the exchange rate, the central bank will mostly use the guidance rate, open market operations and direct intervention policy to prevent the fluctuation of exchange rate. In this case, the interest rate has some influence on the exchange rate, but usually not too big. On the other hand, a relatively stable exchange rate will not have much impact on interest rate, therefore, the linkage effect of interest rate and exchange rate is relatively small.

\subsection{The influence of multiple policy objectives for linkage effect of interest rate and exchange rate}

In twentieth Century 30 years ago, goals of central bank policy mainly is to stabilize the currency. In 1940s, advocate of state intervention in the economy of the Keynes doctrine prevailed, seek full employment has become one of the goals of monetary policy. Since 1950s, many countries in order to protect their own economic strength and international status, regard economic growth as an important goal of monetary policy. Then in 1970s, along with the two dollar crisis, some countries added the balance of international payments to the objectives of monetary policy. Now, many countries' monetary policies also have multiple objectives.

\section{Conclusions}

From the above analysis we can see that, linkage effect between interest rate and exchange rate not only influenced by the level of market-driven, economic opening degree, but also influenced by the policy objectives of central bank, therefore, interest rate and exchange rate linkage mechanism research cannot lump together, according to the actual situation in other countries or regions to specific analysis of specific issues, and the only way the linkage between interest rate and exchange rate is accurate and true.

\section{Acknowledgement}

This research was financially supported by China Economic Research Centre of Quanzhou Normal University.

\section{References}

[1] John Maynard Keynes. A Tract on Monetary Reform[M]. London : Macmillan and Co. Ltd., 1923.

[2] Robert Mundell . The Monetary Dynamics of International Adjustment Under Fixed and Flexible Exchange Rates[J]. Quarterly Journal of Economies, 1963(74) : 75-107.

[3] Rudiger Dornbusch . The Theory of Flexible Exchange Rate Regime and Macroeconomic Policy[J]. 
Scandinavian Journal of Economies, 1976(2) : 255-

276.

[4] Branson , M . International Adjustments and the Dollar : Policy Illusions and Economic Constraints $[\mathrm{J}]$. Economic Policy Coordination of Washington DC : International Monetary Fund, 1988(3) : 25-27.

[5] Ronald I. McKinnon, Kenichi Ohno, Dollar and Yen : Resolving Economic Conflict between the United States and Japan, MIT Press, 1997. 